\title{
Influence of Storage Temperature on the Quality Parameters of Wheat Flour during Short Term Storage
}

\author{
J. Sujitha ${ }^{1}$, M. R. S. Muneer ${ }^{2}$, T. Mahendran ${ }^{1 *}$, and B. Kiruthiga ${ }^{1}$ \\ ${ }^{1}$ Department of Agricultural Chemistry, Faculty of Agriculture, Eastern University, Sri Lanka \\ ${ }^{2}$ Prima Ceylon PVT Ltd., Chinabay, Trincomalee \\ *thevamahen@yahoo.com
}

\begin{abstract}
Among cereals grains, wheat has high potential to produce gluten protein that imparts strength and elasticity to the dough that influences the texture of bakery products. Storage temperature has been shown to affect the quality attributes of wheat flour but only a few research studies were conducted to assess the influence of storage conditions on wheat flour properties. Therefore, a study was carried out to evaluate the influence of storage temperature on the quality characteristics of the wheat flour during short term storage. The freshly milled wheat flour from Prima Ceylon Private Ltd, Trincomalee were stored for 8 weeks at room temperature $\left(35^{\circ} \mathrm{C}\right.$ and the Relative Humidity of 50-60\%) and air conditioned temperature $\left(27^{\circ} \mathrm{C}\right.$ and the Relative Humidity of 60-70\%). The quality characteristics such as moisture, wet gluten, gluten index and ash content and biological characteristics of weevils count and total bacterial count of flour samples were evaluated at 2 weeks interval during the storage period. Moisture content decreased significantly $(p<0.05)$ with the storage duration at both storage temperatures. Visco-elastic properties such as wet gluten and gluten index of flour samples decreased during storage and more markedly affecting the flour quality at room temperature storage. Biological and microbiological characteristics were influenced by storage temperature since the water activity was the main factor influencing their survival. Based on the study, the quality characteristics of wheat flour were better preserved during storage at air conditioned temperature of $27^{\circ} \mathrm{C}$ with $60-70 \%$ Relative Humidity compared to room temperature of $35^{\circ} \mathrm{C}$ with $50-60 \%$ Relative Humidity.
\end{abstract}

Key words: Gluten, rheological property, storage temperature, wheat flour

Wheat (Triticum aestivum) is one of the most commonly grown food crops in the world. Wheat was a key factor enabling the emergence of city-based societies at the start of civilization because it was one of the first crops that could be easily cultivated on a large scale, and had the additional advantage of yielding a harvest that provides long-term storage of food [Delcour \& Hoseney, 2010]. The storage time and conditions have an influence on the technological quality of wheat and result in modifications of the flour parameters [Hruškova \& Machova, 2002]. Milling is the process separating germ from bran and grinding the germ to produce. Milling aims to separate the anatomical parts of the kernel to produce flour with minimal inclusion of bran particles. White flour is made from the endosperm only. Flour composition and functionality determine product quality. A total of $57 \%$ of processed wheat flour is used in the baking and confectionery industry, $16 \%$ is used for domestic consumption, $17 \%$ for dough, $12 \%$ for cookies and $2 \%$ for the production of drugs, glue and animal feeding [Chang \& Ferrari, 2014].

Wheat flour is a dynamic product with both constituent and functional requirements. The uses of flour are many and varied. Wheat flour contains high amount of starches, which are known as polysaccharides. The kinds of flour used in cooking include all-purpose flour, self-rising flour, and cake flour including bleached flour. Constituents such as protein and ash generally dictate the end-use of flour. The higher the protein content the harder and stronger the flour, and the more it will produce crusty or chewy breads [Stone \& Morell, 2009]. The important quality parameters for wheat flour performance are moisture, wet gluten, gluten index, ash, weevils count and flour microbiology. These parameters are the indicators of milling performance and flour quality of the wheat flour. Wheat flour quality is directly related to the wheat gluten formed by mixing the flour with water and with the use of appropriate application of mechanical work to form a visco-elastic network [Raza et al., 2010], whose structure is the basis for bakery and pasta products.

Gluten is a plastic-elastic protein fraction of wheat flour responsible for physical dough properties. It has been generally accepted that any increase in total protein content of the flour results in an increase in gluten content. It is important to note that the quantity of protein or gluten is not a measure for gluten quality. Gluten quality is characterized by the degree of extensibility and elasticity [Hoseney et al., 1986]. Technologists consider gluten as the functional part of dough which influences many product qualities. Although oat, rye, barley and triticale have gluten proteins in their nutritional composition, only wheat has sufficient amounts (8-20\%) for the formation of a strong gluten network, which differentiates it from other cereals [Dendy \& Dobraszczyk, 2009]. The quantity and quality of gluten is among the main parameters to be investigated in order to determine the quality of the 
baked product. Therefore, in this present study efforts have been made to evaluate the changes occur in the parameters determining the quality of wheat under different storage temperatures.

\section{Methods}

\section{Sample Preparation}

This study was carried out at the Prima Ceylon (Pvt.) Limited, Chinabay, Trincomalee. This company is milling wheat grain into wheat flour and distribute throughout Sri Lanka. Freshly milled wheat flour samples of $500 \mathrm{~g}$ were placed in polypropylene bags of $20 \mathrm{x}$ $10 \mathrm{~cm}$ and automatically vacuum packed using a sealing machine (Model: $400 \mathrm{~T}$ ) in a way that no contaminants or insect infestations were allowed. The flour samples were stored for 8 weeks at room temperature of $35^{\circ} \mathrm{C}$ at the $\mathrm{RH}$ of $50-60 \%$ and at air conditioned temperature of $27^{\circ} \mathrm{C}$ at the $\mathrm{RH}$ of $60-70 \%$.

\section{Evaluation of Physico-Chemical Quality Parameters of Wheat Flour}

\section{Moisture Content}

The wheat flour sample of $500 \mathrm{~g}$ was mixed thoroughly to get a uniform distribution of flour. The metal moisture cans were taken and weighed in an analytical balance (Mettler AE 200). Uniformly mixed 10g sample was taken in the moisture cans and the cans were placed in the oven at $130^{\circ} \mathrm{C}$ for 1 hour. The dry weight was recorded after cooling the cans in the desiccator for 15 minutes tills the cans are cooled.

\section{Wet Gluten Content (Glutomatic Method)}

Test chambers were assembled with metal sieves between persplex tube and perforated stainless steel bottom. The sieve was moistened thoroughly to achieve a capillary water bridge which prevents the water loss. Sample of $10 \mathrm{~g}$ was taken in test chambers; $5 \mathrm{ml}$ sodium chloride salt solution was pipetted into the test chamber, and gently shaken to spread the mixture evenly allowed to be washed in gluten machine for 5 minutes. After the washing the test chamber was lowered and the washed wet gluten was taken and it was allowed for centrifugation for 1 minute. The centrifuged wet gluten was weighed and weight was converted to percentage multiplying by 10 .

\section{Gluten Index}

Wheat flour samples of $10 \mathrm{~g}$ were taken in gluten test chambers and $15 \mathrm{ml}$ sodium chloride salt solution was added. The contents were allowed to be washed in glutomatic machine for 5 minutes. After that, the washed wet gluten was taken and it was allowed for centrifugation. The wet gluten was taken from the centrifugation cups in a way that the portion remained inside the cup separately and the gluten which leaked outside the cup separately. Both portions were weighed and the gluten index was calculated.

\section{Ash Content}

Clean ash crucible was taken and their weights were recorded using a digital balance (Mettler AE 200). A flour sample of $5 \mathrm{~g}$ was taken in the crucible and the crucibles were placed in the electric muffle furnace at 600 oC for 6 hours. Later the crucibles were cooled in a desiccator and weighed to get the ash weight of the flour.

\section{Biological Tests}

\section{Weevil Test}

The flour sample was subjected to sieving by $250 \mathrm{mi}-$ crometer pore sized sieve. After that number of weevils present in the sieve was noted.

\section{Total Bacterial Count}

Microbial evaluation is essential part of food safety. Confidence in the food safety and integrity of the supply of good quality wheat flour is an important requirement for consumers. For microbiological test all sample were used in triplicate form. Microorganisms present in the flour samples were enumerated by mixing the sample solution with an agar media and incubated to form visible separate colonies. Potato Carrot Agar (PCA) media was used to investigate the bacterial population in this study. The Petri dishes were arranged for each dilution of flour sample $\left(10^{-1}, 10^{-2}\right.$ and $\left.10^{-3}\right)$. Sample of $1 \mathrm{ml}$ from each dilution tubes was pipette out and inoculated in petri dishes according to serial 10-fold dilution. Then about $1520 \mathrm{ml} \mathrm{PCA}$ media was poured into the petri dishes and they were rotated first clockwise then anticlockwise. The culture was incubated under $35 \mathrm{oC}$ for 2 days and the colonies were counted by placing the petri dishes in colony counter.

\section{Results and Discussion}

\section{Physico-Chemical properties}

The results of the physico-chemical parameters with regard to the moisture, gluten index and ash of wheat flour sample under different storage temperatures are presented in Table 1.

\section{Moisture Content}

Grain moisture is one of the most important factors affecting the quality of flour. As evidenced by the results of the study in Table 1, the storage temperature has a significant effect on the proportion of flour moisture. The initial moisture content of the fresh milled flour was $13.6 \%$. However, after 8 weeks, the moisture content of these samples was decreased to a $12.2 \%$ under room temperature storage and $13.0 \%$ under air conditioned storage, respectively. The moisture losses were low during air conditioned storage than room temperature storage. This may be due to high storage temperature that led to the evaporation of moisture from the part. It was reported by [Fellers \& Bean, 1977] that the mois- 
Table 1: Influence of Storage Temperature on the Physico-Chemical Parameters of Wheat Flour

\begin{tabular}{ccccccc}
\hline \multirow{2}{*}{ Storage Duration (Weeks) } & \multicolumn{2}{c}{ Moisture (\%) } & \multicolumn{2}{c}{ Gluten Index } & \multicolumn{2}{c}{ Ash (\%) } \\
\cline { 2 - 7 } & $\mathbf{R} / \mathbf{T}$ & $\mathbf{A} / \mathbf{T}$ & $\mathbf{R} / \mathbf{T}$ & $\mathbf{A} / \mathbf{T}$ & $\mathbf{R} / \mathbf{T}$ & $\mathbf{A} / \mathbf{T}$ \\
\hline 0 (Fresh) & $13.6^{b}$ & $13.6^{b}$ & $94.17^{b}$ & $94.17^{a b}$ & $0.508^{a}$ & $0.508^{a}$ \\
2 & $12.8^{a b}$ & $13.2^{a}$ & $92.25^{a b}$ & $93.79^{a b}$ & $0.501^{a}$ & $0.506^{a}$ \\
4 & $12.9^{a b}$ & $13.2^{a}$ & $92.07^{a b}$ & $93.09^{a}$ & $0.493^{a}$ & $0.491^{a}$ \\
6 & $12.8^{a b}$ & $13.1^{a}$ & $91.07^{a}$ & $92.97^{a}$ & $0.524^{a}$ & $0.500^{a}$ \\
8 & $12.2^{a}$ & $13.0^{a}$ & $90.01^{a}$ & $92.19^{a}$ & $0.517^{a}$ & $0.510^{a}$ \\
\hline
\end{tabular}

$\mathrm{R} / \mathrm{T}$ - Room Temperature $35^{\circ} \mathrm{C}$ and $\mathrm{RH} 50-60 \%$

$\mathrm{A} / \mathrm{T}$ - Air Conditioned Temperature $27^{\circ} \mathrm{C}$ and $\mathrm{RH} 60-70 \%$

Values are means of triplicates.

Treatment means in a column having common letter(s) are not significantly different by DMRT $5 \%$.

ture content of the wheat flour during storage should be $10-12 \%$ for the safe and long term storage. Flour moisture changes can support the acidity alterations caused by the enzymatic breaking of fytin by fytase, lipolytic fat hydrolysis and proteolysis [Hansen \& Rose, 1996].

\section{Gluten Index}

Cereal chemists are aware that not only quantity but also quality of gluten protein is an important component in producing good quality products. Thus, determination of gluten content is required to assess the quality of the wheat flour. The gluten index of the fresh milled samples decreased from $94.17 \%$ to $90.01 \%$ at room temperature storage and $94.17 \%$ to $92.19 \%$ under air conditioned storage. Storage at room temperature and duration significantly $(p<0.05)$ affected the gluten index of the wheat flour. The gluten index is the measure of gluten elasticity [Raugel et al., 1999]. Since the gluten content is the other important factor determining the baking purpose of the flour (flours with low gluten values are for cookies and biscuits purpose, flours with medium gluten content for cakes production and flours with high gluten values are for bread making purpose). If the gluten index is high that means the proportion of gluten released through the sieve is low indicating that the gluten quality is strong and strength is high. Under refrigerated storage conditions, the gluten index decreased during storage however, the changes was not significant $(p>0.05)$ from the initial value. Therefore, aging of flour caused the gluten index to show a steady decrease, thus the gluten quality remained unchanged during refrigerated storage of flour for 8 weeks. A high gluten index above $95 \%$ indicates strong gluten, while index values lower than $60 \%$ indicate flours too weak for bread production [Violeta \& Georgeta, 2010].

\section{Wet Gluten Content}

Among the wheat flour quality parameters, gluten strength is one of the important characteristics determining the industrial use of the flour for bread, cakes and pasta. As shown in the Figure 1, wet gluten content was affected by storage temperature and relative humidity.

The initial wet gluten content of the fresh milled samples was $39.5 \%$. After 8 weeks of storage, the wet gluten content of the flour samples was dropped to $38.1 \%$ under room temperature storage and $39.2 \%$ under air conditioned storage, respectively. Under refrigerated conditions, the wet gluten content decreased during storage however, the changes was not significantly different $(p>0.05)$ from the initial gluten content of the wheat flour. Based on the values of the wet gluten, the quality of the wheat flour was not significantly affected during refrigerated storage of 8 weeks. [Jennifer, 2013] reported that high temperatures $\left(>35^{\circ} \mathrm{C}\right)$ decrease the gluten quality as the gluten protein become less elastic and more brittle during storage at elevated temperatures for more than 2 weeks. As pointed out by [Amjad, 1990] that the bad effect of high temperatures on the gluten due to increased break ties hydrophobic, which leads to bad influence on the strength of gluten.

\section{Ash Content}

The initial value of ash content of the fresh milled samples was $0.508 \mathrm{~g}$ and it was increased up to $0.517 \mathrm{~g}$ under room temperature storage and $0.51 \mathrm{~g}$ under air conditioned storage, respectively. However, these increments are not significant. But at the end of $9^{\text {th }}$ week the ash content of the flour sample stored under room temperature decreased to a lower value than the ash content under air conditioned temperature. That means under room temperature storage flour is bleached by the high temperature due to oxidation of lipids. So the ash content gets lower value.

\section{Biological Quality Parameters}

The weevil counts and total bacterial count under different storage temperatures are presented in Table 2. 
Table 2: Influence of Storage Temperature on Biological Quality of Wheat Flour

\begin{tabular}{|c|c|c|c|c|}
\hline \multirow{2}{*}{$\begin{array}{c}\text { Storage Duration } \\
\text { (Weeks) }\end{array}$} & \multicolumn{2}{|c|}{ Weevil Count } & \multicolumn{2}{|c|}{ Total Bacterial Count } \\
\hline & $\mathbf{R} / \mathbf{T}$ & $\mathrm{A} / \mathrm{C}$ & $\mathbf{R} / \mathbf{T}$ & $\mathrm{A} / \mathrm{C}$ \\
\hline 0 (Fresh) & 0 & 0 & 470 & 470 \\
\hline 2 & 0 & 0 & 410 & 510 \\
\hline 4 & 0 & 0 & 580 & 530 \\
\hline 6 & 0 & 0 & 610 & 640 \\
\hline 8 & 0 & 0 & 500 & 750 \\
\hline
\end{tabular}

$\mathrm{R} / \mathrm{T}$ - Room Temperature $35^{\circ} \mathrm{C}$ and $\mathrm{RH} 50-60 \%$

$\mathrm{A} / \mathrm{T}$ - Air Conditioned Temperature $27^{\circ} \mathrm{C}$ and $\mathrm{RH} 60-70 \%$

Values are means of triplicates.

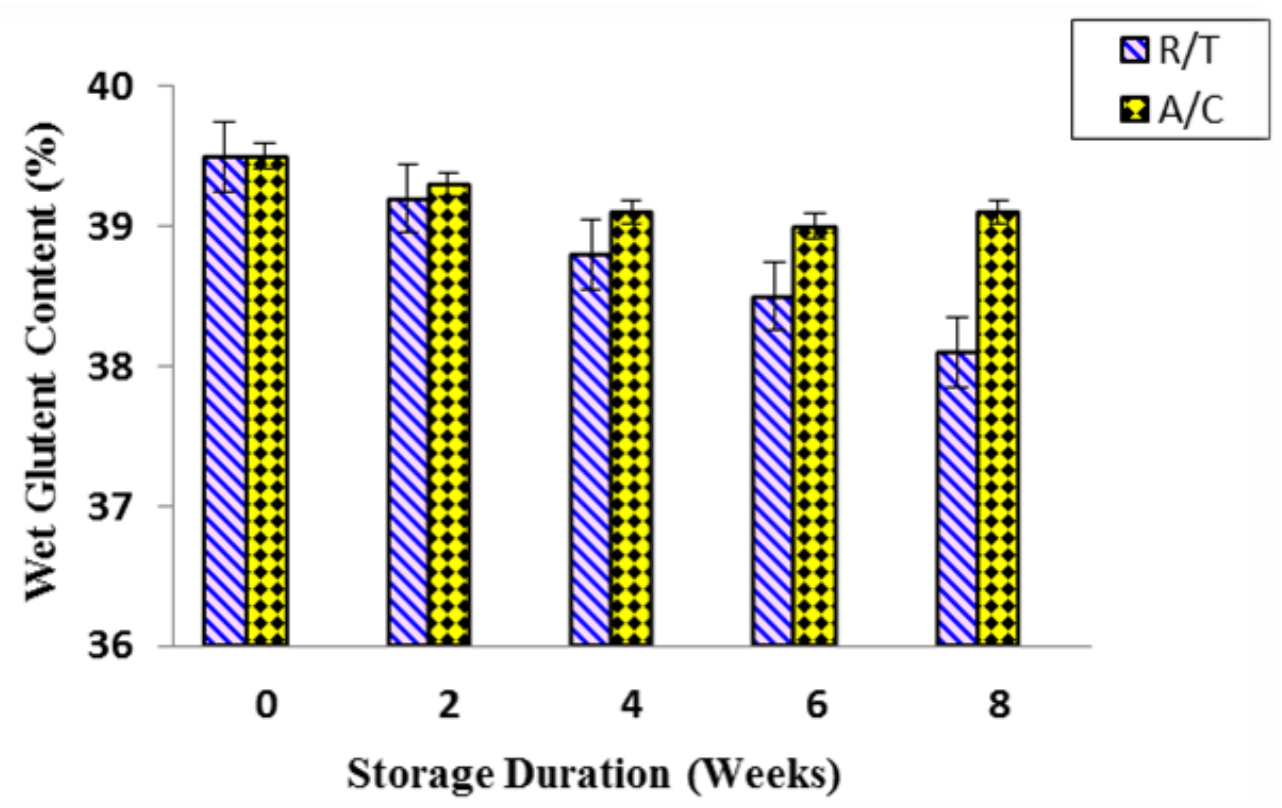

Figure 1: Influence of Storage Temperature on Wet Gluten Content of Wheat Flour

$\mathrm{R} / \mathrm{T}$ - Room Temperature $35^{\circ} \mathrm{C}$ and $\mathrm{RH} 50-60 \%$

$\mathrm{A} / \mathrm{T}$ - Air Conditioned Temperature $27^{\circ} \mathrm{C}$ and $\mathrm{RH} 60-70 \%$

Values are means of triplicates.

\section{Weevil Test}

According to the result from Table 2, the weevils were not observed in samples even after 8 weeks of storage under both storage temperature conditions. However, it is recommended that storing flour samples under air conditioned storage with the temperature below $15^{\circ} \mathrm{C}$ would give the best results and improve the shelf life of the wheat flour with acceptable quality [Kent \& Evers, 1993].

\section{Total Bacterial Count}

The effect of temperature on flour bacterial count mainly depended on the flour moisture content at that time. It is proved from the past researches that the water activity plays a key role in the microbiology of flour, it is important to relate the flour moisture content to flour microbiology. The different storage temperatures influenced the bacterial count of flour samples differently. The initial bacterial count of flour was 470 at $13.6 \%$ moisture content. The results confirmed that both the storage temperature and storage time did not have a significant influence on the bacterial count of flour sample. The bacterial counts of sample were very low under both storage conditions from initially but the bacterial population at the end of 8th week under room temperature is lower than that in the air conditioned storage. Normally the bacterial population of the fresh milled sample should be in the range of 1000 to 100,000 per gram [Jennifer, 2013]. But the bacterial populations of flour samples under two different storage were lower 
than 1000. This means that the microbial quality of the flour is good following 8 weeks storage.

\section{Conclusions}

The quality of the wheat flour is the main consideration of the wheat grain millers and bakers to get a high quality end product with a maximum keeping quality. The tested storage temperatures significantly influence on the moisture contents of the wheat flour during storage. Gluten index reduced in during storage at both temperatures and this was more pronounced in the flour stored at room temperature of Room Temperature $35^{\circ} \mathrm{C}$ and $\mathrm{RH} 50-60 \%$. The ash content was not significantly affected by the temperatures and the storage duration. There were no weevils observed in samples stored under both temperatures. The storage temperatures significantly influence the quality parameters of wheat flour and play significant role in aging process of the flour. It is important to take preventive measures for maintaining the gluten content unchanged and to safeguard the flour quality unaffected. Therefore, the freshly milled wheat flour could be recommended to store under air conditioned temperature of $27^{\circ} \mathrm{C}$ with $60-70 \%$ $\mathrm{RH}$ to maintain the flour quality characteristics at optimum level for better baking quality and to extend the shelf life.

\section{References}

Amjad, B. S. (1990) Bread and AlmajnatMosul University, Ministry of Higher Education and Scientific Research. Iraq, pp.30-60.

Chang, Y. K. \& Ferrari, M. C. (2014). A study on the methods used for wheat flour analysis and wheat gluten quality. Food Science and Technology, v.34(2), pp.235-242.

Delcour, J. \& Hoseney, R. C. (2010). Principles of Cereal Science and Technology. Academic Press, UK. pp. 345-412.

DOI:http://dx.doi.org/10.1094/9781891127632

Dendy, D. V. \& Dobraszczyk, B. J. (2009). Cereals and Cereal Products: Technology and Chemistry. News Letter: 26, Tropical Products Institute, London, UK. pp. 26-32.

Fellers, D. A. \& Bean, M. M. (1977). Storage stability of wheat-based foods: A Review. Journal of Food
Science, v. 42(5), pp.1143-1147.

DOI:https://doi.org/10.1111/j.1365-2621.1977. tb14446.x

Hansen, L. A. \& Rose, M. S. (1996). Sensory acceptability is inversely related to development of fat rancidity in bread made from stored flour. Journal of the Academy of Nutrition and Dietetics, v.96(8), pp.792799 .

Hoseney, R. C., Zeleznak, K., \& Lai, C. S. (1986). Wheat gluten-a glassy polymer. Cereal Chemistry, v.63(3), pp.285-286.

Hruškova, M. A. R. \& Machova, D. A. (2002). Changes of wheat flour properties during short term storage. Czech Journal of Food Science, v. 20(4), pp.125-130. DOI:https://doi.org/10.17221/3522-CJFS

Jennifer, S. J. (2013). Changes in physico-chemical characteristics of wheat flour during storage and the effects on baking quality. Journal of the Food and Agriculture. v.210(2), pp.412-420.

Kent, N.L. \& Evers, A. D. (1993). Technology of Cereals. $4^{\text {th }}$ ed. Elsevier Sci. Ltd, U.K. pp. 104-129.

Marathe, S. A., Machaiah, S. P., Rao, B. Y. \& Pednekar, G.E. (2002). Extension of shelf life of wheat flour using gamma radiation. International Journal of Food Science and Technology. v. 37(2): pp.163168.

Raugel, P. J., Robertson, P.O. \& David, C. T. (1999). Perten Instruments. In Rapid Food Analysis and Hygiene Monitoring. Springer Berlin Heidelberg. pp. 439-455.

Raza, S., Khalil, S. Naseem, K. \& Masud, P. K. (2010). Effect of household storage temperature on the physico-chemical characteristics of the wheat flour. Sarhad Journal of Agriculture. v. 26(2): pp.275-287.

Stone, B. \& Morell, M. K. (2009). Carbohydrates. In. Wheat Chemistry and Technology. AACC International, USA. pp. 244-265.

DOI:http://dx.doi.org/10.1094/9781891127557.009

Violeta I. C. \& Georgeta S. P. (2010) Comparative evaluation of wet gluten quantity and quality through different methods, The Annals of the University Dunarea de Jos of Galati, Fascicle. Food Technology. v. 34(2), pp.231-239. 